\title{
Nitrogen Recovery and Transport Efficiency of Winter Rapeseed and Residual Nitrogen Effect on Subsequent Sesame using ${ }^{15} \mathrm{~N}$ Labelling Technique
}

\author{
Ruiqing Wang ${ }^{1,2}$, Jing Zhang ${ }^{1}$, Tao Luo ${ }^{1}$, Mohammad Nauman Khan ${ }^{1}$, Liyong $\mathrm{Hu}^{{ }^{*}}$ and Lingen Wei ${ }^{2}$ \\ ${ }^{1}$ MOA Key Laboratory of Crop Ecophysiology and Farming System in the Middle Reaches of the Yangtze River, College of \\ Plant Science and Technology, Huazhong Agricultural University, Wuhan 430070, P. R. China \\ ${ }^{2}$ Soil Fertilizer and Resource Environment Institute, Jiangxi Academy of Agricultural Sciences, Nanchang 330200, P. R. China \\ *For correspondence: liyonghu@mail.hzau.edu.cn
}

\begin{abstract}
In China, the application rate of nitrogen in rapeseed is high, but the uptake and utilization efficiency is low, which may cause irreversible environmental pollution. Use of efficient nitrogen rate and to improve nitrogen recovery, transport and residues management is important for crop productivity and sustaining the environment. Therefore, a pot was conducted using two winter rapeseed cultivars of Huayouza No.9 (HZ9) and Huashuang No.5 (HS5) under two N levels $\left(0.15-\mathrm{N}_{1}\right.$ and $0.30-\mathrm{N}_{2} \mathrm{~g}$ N.kg ${ }^{-1}$ soil). The ${ }^{15} \mathrm{~N}$-uera was applied before sowing (basal) and at stems elongation stage (topdressing). The results indicated that ${ }^{15} \mathrm{~N}$ recovery efficiency $\left({ }^{15} \mathrm{NRE}\right)$ of HS5 under $\mathrm{N}_{1}$ increased by 5.89 percentage points compared to $\mathrm{N}_{2}$, and the most obvious difference was observed in grain. However, no significant difference was observed in HZ9 between the two N levels. The ${ }^{15} \mathrm{~N}$ transport efficiency $\left({ }^{15} \mathrm{NTE}\right)$ of the $\mathrm{N}_{1}$ treatment $(37.62 \sim 37.70 \%)$ was much higher than that of the $\mathrm{N}_{2}$ treatment, with the difference mainly observed in stem (4.33 5.03\%). The ${ }^{15} \mathrm{NTE}$ of basal was significantly higher than that of topdressing, with the difference mainly found in leaves $(14.02 \sim 19.52 \%)$. The ${ }^{15} \mathrm{NRE}$ under topdressing treatment $(56.85 \sim 61.60 \%)$ increased 8.18 and 8.58 percentage points relative to that under basal treatment, with the main difference observed in grain and pericarp. Additionally, about $1.62 \%$ nitrogen from rapeseed season in two $\mathrm{N}$ levels was absorbed by the subsequent sesame crop, with its yield increased by $26.00 \sim 89.19 \%$ compared to the control. The average ${ }^{15} \mathrm{NRE}$ of sesame from basal and topdressing was $1.91 \%$ and $1.34 \%$, with a yield increase of $16.22 \%$ and $59.50 \%$ over the control, respectively. The integrated data indicated that higher $\mathrm{N}$ recovery and transport efficiency can be achieved by adequacy reducing application rate and increasing the proportion of topdressing, and the residual soil nitrogen of rapeseed can be recovered to some extent by planting sesame. (C) 2017 Friends Science Publishers
\end{abstract}

Keywords: ${ }^{15} \mathrm{~N}$ Recovery efficiency; ${ }^{15} \mathrm{~N}$ Transport efficiency; Cropping patterns; Residual N effect; Sesame; Winter rapeseed

\section{Introduction}

The Yangtze River Basin, one of the major winter rapeseed production regions in China, accounts for one-fifth of the rapeseed yield and cultivation area in the world ( $\mathrm{Li}$ et al., 2015). However, the nitrogen recovery efficiency of rapeseed was about 34.6\% in Yangtze River Basin of China, which easy led to environmental pollution (Zou et al., 2011). Most previous studies have demonstrated that nitrogen fertilizer could promote rapeseed growth, which may ultimately improve nitrogen absorption, accumulation and nitrogen requirement of rapeseed grain, but nitrogen fertilizer agronomic efficiency, partial factor productivity and recovery efficiency significantly decreased with increasing nitrogen supply(Gan et al., 2008; Schulte-auf'mErley et al., 2011; Johnson et al., 2013).

Winter rapeseed showed relatively high nitrogen absorption ability, but there was still a certain amount of soil residual nitrogen after harvest (Dresbøll et al., 2016). To date, the percentage of residual nitrogen recovery efficiency has not been fully explored. It has been reported that the recovery efficiency of residual soil nitrogen was affected by nitrogen fertilizer rate (Sepaskhah and Tafteh, 2012), fertilizing method (Xu et al., 2015) and residue incorporation (Ichir et al., 2003). The rapeseed and sesame cropping pattern was one of the important cropping models in the middle reaches area of Yangtze River, China. Hence, sesame is considered as a suitable crop for measuring $\mathrm{N}$ recovery efficiency of soil residual nitrogen of rapeseed.

Currently, ${ }^{15} \mathrm{~N}$ isotope labeling method is used as an effective way for studying nitrogen fertilizer use efficiency and nitrogen transport efficiency (Gironde et al., 2015a, b). Nitrogen uptake and utilization process also involves the conversion of nitrogen source-sink in the plant body. The

To cite this paper: Wang, R., J. Zhang, T. Luo, M.N. Khan, L. Hu and L. Wei, 2017. Nitrogen recovery and transport efficiency of winter rapeseed and residual nitrogen effect on subsequent sesame using ${ }^{15} \mathrm{~N}$ labelling technique. Int. J. Agric. Biol., 19: 673-681 
growth period from emergence to early flowering is generally considered as the accumulation period of plant $\mathrm{N}$ source, and the stem and leaves were two major sources for apparent $\mathrm{N}$ remobilization to the pods. Nitrogen uptake after entering the early flowering stage is adjusted by the sink size. Especially, remobilization of $\mathrm{N}$ from stems and leaves was more important for pod $\mathrm{N}$ accumulation than $\mathrm{N}$ uptake after florescence. In order to decrease the crop-inherent high $\mathrm{N}$ budget surplus of winter rapeseed requires, and it should increase the low $\mathrm{N}$ remobilization efficiency particularly of pericarp $\mathrm{N}$ to the grains (Wang et al., 2011; KoeslinFindeklee and Horst, 2016; Wang et al., 2016). Meanwhile the nitrogen transport efficiency is determined by the $\mathrm{N}$ supply levels and the genotypes (Gironde et al., 2015b). Cai et al. (1995) investigated the rapeseed nitrogen recovery efficiency by ${ }^{15} \mathrm{~N}$ labelling technique and reported that rapeseed plant recovery efficiency of nitrogen as basal and topdressing at the flowering stage was $44.0 \%$ and $33.4 \%$ of the applied N, respectively. Meanwhile, many researchers maintained that the apparent $\mathrm{N}$ transport efficiency of rapeseed grain was about $41.0 \sim 65.0 \%$ from vegetative tissues, and the transport capacity was obviously higher under moderate nitrogen stress conditions than under normal or severe nitrogen stress conditions, with the apparent $\mathrm{N}$ transport efficiency of rapeseed grain being roughly 70-94\% (Hocking et al., 1997; Rossato et al., 2001; Malagoli et al., 2005; Gombert et al., 2010; Franzaring et al., 2012; Gironde et al., 2015a). However, there have been few reports available on the use efficiency of nitrogen fertilizer as basal and topdressing in different organs of rapeseed and the residual $\mathrm{N}$ recovery efficiency by the subsequent crop. To gain novel insights into these questions, the effects of different $\mathrm{N}$ levels and application time on the use efficiency of nitrogen fertilizer as basal and topdressing were studied by using the ${ }^{15} \mathrm{~N}$ labeling method in this paper.

The objectives of this study were to explore the use efficiency of nitrogen fertilizer as basal and topdressing under two levels and two growth stages in terms of nitrogen recovery efficiency, transport efficiency after the early flowering stage and residual soil nitrogen recovery efficiency by planting sesame. This research provides theoretical support for the recovery efficiency of $\mathrm{N}$ fertilizer in rapeseed and residual soil nitrogen.

\section{Materials and Methods}

\section{Plant Materials and Growth Conditions}

Two rapeseed cultivars and one sesame cultivar were used as planting materials in this study. Huayouza No. 9 (HZ9) and Huashuang No.5 (HS5), a hybrid and a conventional rapeseed cultivar, were provided by Huazhong Agricultural University. Ganzhi No. 5 (GZ5) was a conventional cultivar of black sesame which was provided by the Crop Institute of
Jiangxi Academy of Agricultural Sciences, China. The pot experiment was carried out at the glasshouse of the College of Plant Science and Technology, Huazhong Agricultural University, Wuhan, Hubei Province, China (114'22'E, $\left.30^{\circ} 29^{\prime} \mathrm{N}\right)$. Soil properties were: $\mathrm{pH} 6.1,19.8 \mathrm{~g}$ organic matter $\mathrm{kg}^{-1}, 10.9 \mathrm{~g}$ total $\mathrm{N} \mathrm{kg}^{-1}, 16.2 \mathrm{mg}$ Olsen-P kg${ }^{-1}$, and $75.2 \mathrm{mg} \mathrm{NH}_{4} \mathrm{OAc}$-extractable $\mathrm{K} \cdot \mathrm{kg}^{-1}$.

\section{Experimental Design}

The pot experiment was conducted using two factors randomized block design. Nitrogen application time $\left(\mathrm{T}_{1^{-}}\right.$ basal- $60 \%$ before sowing and $\mathrm{T}_{2}$-topdressing- $40 \%$ at stem elongation stage) was the first factor, and nitrogen application rate $\left(\mathrm{N}_{1}-0.15\right.$ and $\mathrm{N}_{2}-0.30, \mathrm{~g} \mathrm{~N} \cdot \mathrm{kg}^{-1}$ soil) was the second factor with one control $\left(\mathrm{N}_{0}\right)$ set for comparison. Low nitrogen $\left(\mathrm{N}_{1}\right)$ and high nitrogen $\left(\mathrm{N}_{2}\right)$ represented the amount of 120 and $240 \mathrm{~kg} \mathrm{~N} \cdot \mathrm{ha}^{-1}$. Treatments details for HZ9 and HS5 are shown in Table 1. Plants were grown in $15 \mathrm{~L}$ containers (bottom diameter: $0.225 \mathrm{~m}$, top diameter: 0.330 $\mathrm{m}$, height: $0.250 \mathrm{~m}$ ) including $10 \mathrm{~kg}$ soil and $5 \mathrm{~kg}$ sand. Eight replications were conducted for each treatment in the growth season of rapeseed and five replications were conducted for each treatment in the growth season of sesame.

Rapeseed seeds were directly sown for each pot by hand on $4^{\text {th }}$ November, 2013. Six rapeseed seeds were sown in each pot, and seedlings were thinned to two plants per pot by hand at the $4^{\text {th }}$ leaves stage. Under a low nitrogen conditions, the stem elongation stage, early flowering stage, and maturity stage of HZ9 and HS5 began on February 27 and March 3, March 14 and March 19, May 5 and May 7, 2014, respectively; under a high nitrogen condition, early flowering stage and maturity stage of HZ9 and HS5 were delayed by one or two days relative to those at a low nitrogen level. Eight sesame seeds were directly sown in each pot by hand on May 18, 2014, with four sesame plants maintained in each pot at the $3^{\text {rd }}$ couple leaves stage, and the pots were harvested on August 22, 2014.

Fertilizers used were urea for $\mathrm{N}(46.4 \%)$, single superphosphate for $\mathrm{P}_{2} \mathrm{O}_{5}(12.0 \%)$, potassium chloride for $\mathrm{K}_{2} \mathrm{O}(60.0 \%)$ and borax for $\mathrm{B}(10.0 \%)$. The doses were $0.075 \mathrm{P}_{2} \mathrm{O}_{5}, 0.105 \quad \mathrm{~K}_{2} \mathrm{O}$, and $0.025 \mathrm{~g} \mathrm{~B}$ (g.kg-1 soil), respectively. $\mathrm{P}_{2} \mathrm{O}_{5}, \mathrm{~K}_{2} \mathrm{O}$ and $\mathrm{B}$ were applied once as a basal dose before sowing. The ${ }^{15} \mathrm{~N}$ abundance in urea $(\mathrm{N} 46.4 \%$, Shanghai Chemical Industry Research Institute, Shanghai, China) was $10.16 \% .{ }^{15} \mathrm{~N}$ fertilizer was fully dissolved in 500 $\mathrm{mL}$ water and then was poured into the pots. During seedling stage and stem elongation stage, both the rapeseed and sesame plants were regularly provided with $500 \mathrm{~mL}$ water to prevent the plants from wilting, but with 1,000 $\mathrm{mL}$ water during flowering and maturity stages. Pests, diseases, birds, and weeds were controlled as per requirement to avoid yield losses. 
Table 1: Nitrogen fertilizer rate of different treatments in rapeseed and sesame cropping pattern (unit: $\mathrm{g} \mathrm{N}^{\mathrm{kg}}{ }^{-1}$ soil)

\begin{tabular}{llll}
\hline Treatment & Basel of rapeseed $(60 \%)$ & Topdressing of rapeseed $(40 \%)$ & Sesame \\
\hline $\mathrm{N}_{0}-0$ & 0 & 0 & 0 \\
$\mathrm{~N}_{1} \mathrm{~T}_{1}-0.15$ & $0.09 \#$ & 0.06 & 0 \\
$\mathrm{~N}_{1} \mathrm{~T}_{2}-0.15$ & 0.09 & $0.06 \#$ & 0 \\
$\mathrm{~N}_{2} \mathrm{~T}_{1}-0.30$ & $0.18 \#$ & 0.12 & 0 \\
$\mathrm{~N}_{2} \mathrm{~T}_{2}-0.30$ & 0.18 & $0.12 \#$ & 0 \\
\hline
\end{tabular}

\# indicated ${ }^{15} \mathrm{~N}$ labeling fertilizer; $\mathrm{N}_{0}, \mathrm{~N}_{1}$ and $\mathrm{N}_{2}$ represented $0,0.15$ and $0.30 \mathrm{~g} \mathrm{~N} \cdot \mathrm{kg}^{-1}$ soil, respectively; $\mathrm{T}_{1}$ and $\mathrm{T}_{2}$ indicated basal labelling and topdressing labelling

\section{Data Collection}

At the early flowering stage and maturity stage of rapeseed as well as the maturity stage of sesame, three pots of basal and topdressing labelling treatments were harvested separately. The rapeseed samples were divided into roots, stems, and leaves, followed by drying at $105 \square$ for half an hour, then at $80 \square$ for four days to a constant weight (dry weight). The data of nitrogen content and ${ }^{15} \mathrm{~N}$ abundance were determined at Crop Physiological Ecology and Tillage Key Laboratory in the Middle Reaches of Yangtze River of the Ministry of Agriculture, College of Plant Science and Technology, Huazhong Agricultural University, using Vario ISOTOPE Cube CN (Isoprime-100, Elementar Analysensysteme GmbH, Germany).

Related nitrogen use efficiency indexes were calculated according to the following equations:

(1) $\mathrm{N}_{\mathrm{dff}}(\mathrm{N}$ derived from fertilizer; $\%)=\left(\right.$ atom $\%{ }^{15} \mathrm{~N}$ plant organ -0.3663$) \times 100 /\left(\right.$ atom $\%{ }^{15} \mathrm{~N}$ in fertilizer$0.3663)$;

(2) $\mathrm{N}_{\text {uptake }}$ (Fertilizer $\mathrm{N}$ uptake by whole plant from basal or topdressing; g.plant $\left.{ }^{-1}\right)=$ total nitrogen content $X$ ${ }^{15} \mathrm{Ndff}$ (basal or topdressing);

(3) $\mathrm{NRE}_{\text {organ }}\left[{ }^{15} \mathrm{~N}\right.$ Recovery Efficiency of plant organs (roots, stems, leaves, pericarps, grains);\%]= $\mathrm{N}_{\text {uptake }} \times 100 \%$ /total ${ }^{15} \mathrm{~N}$ supply(Choudhury and Khanif, 2001);

(4) $\mathrm{NTA}_{\text {oragn }}($ Nitrogen Transport Amount; g) $=$ nitrogen accumulation amounts of different organs at early flowering stage - nitrogen accumulated amounts of vegetative organs at maturity stage;

(5) $\mathrm{NTE}_{\text {oragn }}($ Nitrogen Transport Efficiency; \%) = $\mathrm{NTA}_{\text {organ }} \times 100 \%$ /total accumulation nitrogen of whole plant at early flowering stage (Ji et al. 2005).

The temperature data (from November 4, 2013 to August 30,2014) in glasshouse were recorded once per hour with $0.1^{\circ} \mathrm{C}$ precision by an automatic temperature recording instrument (DT618A, Hataike Science and Technology Corporation, Hangzhou, China). The recorded data were used to determine the average temperature per day, the maximum, minimum and mean temperature of one month.

\section{Statistical Analyses}

Two-way ANONA was used to analyze all datas with the statistical software package SAS 9.1. All figures were designed by Origin 8.0. Block and block interactions were considered as random effects, and the application rate and time of nitrogen were considered as fixed effects. Fisher's least significant difference (LSD) was used to test the difference between means of each treatment at 0.05 and 0.01 probability levels.

\section{Results}

\section{Temperature during the Experimental Season}

The mean, maximum and minimum temperature followed roughly the similar trend during the experimental season. The mean and minimum temperature decreased from seeding to the beginning of the stem elongation stage, followed by a gradual increase from March 2014 as the rapeseed reached the maturity stage, and it moderately decreased in August, 2014 (Fig. 1). However, the maximum temperature began to rise in January, 2014. The lowest and the highest temperature in the experimental season were $1.0^{\circ} \mathrm{C}$ (February, 2014) and $34.4^{\circ} \mathrm{C}$ (July, 2014), respectively. No extreme temperature was recorded during the growth season of rapeseed and sesame.

\section{Yield and Yield Components of Rapeseed under Different Treatments}

As the nitrogen application rate increased, the yield, pod number plant ${ }^{-1}$ of the rapeseed increased significantly (Table 2). Furthermore, the yield and pod number plant ${ }^{-1}$ of $\mathrm{N}_{2}$ significantly increased by $28.16 \%$ and $16.51 \%$ in HZ9 compared to those of $\mathrm{N}_{1}$ (Table 2). Nonetheless, no significant difference was observed in yield and pod number plant $^{-1}$ of HS5 between $\mathrm{N}_{1}$ and $\mathrm{N}_{2}$ in this study, and no significant difference was observed in all traits between $\mathrm{T}_{1}$ and $\mathrm{T}_{2}$. Compared to HS5, the pod number plant ${ }^{-1}$ of HZ9 was $19.58 \%$ higher, but 1000 -seed weight was $6.84 \%$ lower (Table 2).No significant interaction was noticed for $\mathrm{N} \times \mathrm{T}$ of all traits (Table 2). These results demonstrated that the application rate of nitrogen is the main factor affecting rapeseed yield and yield components.

\section{The Percentage of $N$ Derived from Fertilizer}

The ${ }^{15} \mathrm{~N}$ derived from fertilizer $\left({ }^{15} \mathrm{~N}_{\mathrm{dff}}\right)$ for different organs such as grain, stem, pericarp and root under high nitrogen was significantly increased by $3.82 \sim 7.56$ percentage points compared to low nitrogen in HZ9 and HS5 (Table 3). The results indicated that genotype differences exhibited significant in $\mathrm{N}_{\text {dff }}$ for all organs at the flowering stage under the two nitrogen levels, and the difference of the low nitrogen-efficient variety was 
Wang et al. / Int. J. Agric. Biol., Vol. 19, No. 4, 2017

Table 2: Yield and yield components of two rapeseed cultivars under different nitrogen application time points and rates

\begin{tabular}{|c|c|c|c|c|}
\hline Treatment & Yield (g.plant ${ }^{-1}$ ) & Pod number per plant (pieces.plant ${ }^{-1}$ ) & Seed number per pod/pieces & 1000-seed weight $(\mathrm{g})$ \\
\hline \multicolumn{5}{|c|}{ 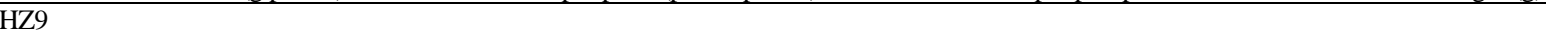 } \\
\hline $\mathrm{T}_{1}$ & $9.38 \mathrm{a}$ & $171.33 \mathrm{a}$ & $15.51 \mathrm{a}$ & $3.40 \mathrm{a}$ \\
\hline $\mathrm{T}_{2}$ & $8.59 \mathrm{a}$ & $156.02 \mathrm{a}$ & $14.46 \mathrm{a}$ & $3.68 \mathrm{a}$ \\
\hline $\mathrm{N}_{0}$ & $1.12 \mathrm{c}$ & $25.25 \mathrm{c}$ & $12.92 \mathrm{a}$ & $3.60 \mathrm{a}$ \\
\hline $\mathrm{N}_{1}$ & $11.33 b$ & $215.13 b$ & $15.47 \mathrm{a}$ & $3.44 a$ \\
\hline $\mathrm{N}_{2}$ & $14.52 \mathrm{a}$ & $250.65 \mathrm{a}$ & $16.56 \mathrm{a}$ & $3.59 \mathrm{a}$ \\
\hline $\mathrm{T}$ & ns & ns & ns & ns \\
\hline $\mathrm{N}$ & $* *$ & $* *$ & ns & ns \\
\hline $\mathrm{N} \times \mathrm{T}$ & ns & ns & ns & ns \\
\hline \multicolumn{5}{|l|}{ HS5 } \\
\hline $\mathrm{T}_{1}$ & $8.51 \mathrm{a}$ & $134.92 \mathrm{a}$ & $15.96 \mathrm{a}$ & $3.75 \mathrm{a}$ \\
\hline $\mathrm{T}_{2}$ & $8.92 \mathrm{a}$ & $138.83 \mathrm{a}$ & $15.73 \mathrm{a}$ & $3.86 \mathrm{a}$ \\
\hline $\mathrm{N}_{0}$ & $1.36 \mathrm{~b}$ & $27.17 \mathrm{~b}$ & $15.99 \mathrm{a}$ & $3.15 b$ \\
\hline $\mathrm{N}_{1}$ & $12.14 \mathrm{a}$ & $188.63 \mathrm{a}$ & $16.14 \mathrm{a}$ & $4.02 \mathrm{a}$ \\
\hline $\mathrm{N}_{2}$ & $12.65 \mathrm{a}$ & $194.83 \mathrm{a}$ & $15.41 \mathrm{a}$ & $4.23 \mathrm{a}$ \\
\hline $\mathrm{T}$ & ns & ns & ns & ns \\
\hline $\mathrm{N}$ & $* *$ & $* *$ & ns & $* *$ \\
\hline $\mathrm{N} \times \mathrm{T}$ & ns & ns & ns & ns \\
\hline
\end{tabular}

Table 3: The percentage of nitrogen derived from ${ }^{15} \mathrm{~N}$ fertilizer $\left({ }^{15} \mathrm{~N}_{\mathrm{dff}} / \%\right)$ for different organs at different stages

\begin{tabular}{|c|c|c|c|c|c|c|c|}
\hline \multirow[t]{2}{*}{ Treatment } & \multicolumn{3}{|c|}{ Early Flowering Stage } & \multicolumn{4}{|c|}{ Maturity Stage } \\
\hline & Root & Stem & Leaf & Grain & Pericarp & Stem & Root \\
\hline \multicolumn{8}{|l|}{ HZ9 } \\
\hline $\mathrm{N}_{1}$ & 41.63 & 42.14 & 41.05 & 35.77 & 34.85 & 35.94 & 33.23 \\
\hline $\mathrm{N}_{2}$ & 39.96 & 42.81 & 41.30 & 41.35 & 40.46 & 39.76 & 39.56 \\
\hline $\mathrm{T}_{1}$ & 49.86 & 49.53 & 55.29 & 44.67 & 43.55 & 45.77 & 51.35 \\
\hline $\mathrm{T}_{2}$ & 31.72 & 35.42 & 27.05 & 32.44 & 31.76 & 29.93 & 21.44 \\
\hline $\mathrm{N}$ & ns & $\mathrm{ns}$ & $\mathrm{ns}$ & $* *$ & $* *$ & $* *$ & $* *$ \\
\hline $\mathrm{T}$ & $* *$ & $* *$ & $* *$ & $* *$ & $* *$ & $* *$ & $* *$ \\
\hline $\mathrm{N} \times \mathrm{T}$ & $\mathrm{ns}$ & $* *$ & $* *$ & ns & $* *$ & $* *$ & ns \\
\hline \multicolumn{8}{|l|}{ HS5 } \\
\hline $\mathrm{N}_{1}$ & 39.44 & 40.65 & 40.56 & 34.77 & 34.22 & 34.03 & 33.44 \\
\hline $\mathrm{N}_{2}$ & 43.67 & 44.25 & 42.62 & 42.33 & 41.13 & 40.52 & 39.30 \\
\hline $\mathrm{T}_{1}$ & 52.07 & 46.47 & 52.04 & 44.20 & 42.48 & 43.71 & 51.22 \\
\hline $\mathrm{T}_{2}$ & 31.04 & 38.42 & 31.14 & 32.89 & 32.86 & 30.84 & 21.52 \\
\hline $\mathrm{N}$ & $* *$ & $* *$ & $* *$ & $* *$ & $* *$ & ** & $* *$ \\
\hline $\mathrm{T}$ & $* *$ & $* *$ & $* *$ & $* *$ & $* *$ & $* *$ & $* *$ \\
\hline $\mathrm{N} \times \mathrm{T}$ & $*$ & $* *$ & $* *$ & ns & ns & $\mathrm{ns}$ & $* *$ \\
\hline
\end{tabular}

$\mathrm{N}, \mathrm{T}$ and $\mathrm{N} \times \mathrm{T}$ represented nitrogen application rate and nitrogen application time, interaction of nitrogen application rate and nitrogen application time respectively; *, ** and ns indicated significant treatment effects at $\mathrm{P} \leqslant 0.05, \mathrm{P} \leqslant 0.01$ and not significant, respectively; HZ9 and HS5 represented Huayouza No. 9 and Huashuang No.5, respectively; $\mathrm{N}_{1}$ and $\mathrm{N}_{2}$ represented 0.15 and $0.30 \mathrm{~g} \mathrm{~N} . \mathrm{kg}^{-1}$ soil; $\mathrm{T}_{1}$ and $\mathrm{T}_{2}$ represented basal labelling and topdressing labelling

more sensitive. After entering the maturity stage, significant differences were observed in $\mathrm{N}_{\mathrm{dff}}$ for all organs in HZ9 and HS5.

At the two stages, the $\mathrm{N}_{\mathrm{dff}}$ values of all organs were significantly higher under basal treatment than under topdressing treatment in HZ9 and HS5. At the maturity stage, the $\mathrm{N}_{\mathrm{dff}}$ values of plant root and stem were reduced by 5.49 7.58 and 9.52 10.28 percentage points under topdressing nitrogen treatment compared to the early flowering stage. The ${ }^{15} \mathrm{~N}_{\text {dff }}$ of root under topdressing was $21.44 \%$, a decrease of $30 \%$ compared to that of basal treatment. The ${ }^{15} \mathrm{~N}_{\mathrm{dff}}$ values of grain, stem and pericarp were around $31.0 \%$, which was a decrease of $9.62 \sim 15.84$ percentage points relative to that under basal treatment
(Table 3).

A significant interaction of nitrogen application rate and time with $\mathrm{N}_{\mathrm{dff}}$ of stem and leaf were observed in HZ9 and HS5 at the early flowering stage, but not observed for the grain,pericarp and stem of HS5 at the maturity stage (Table 3).

\section{${ }^{15}$ N Recovery Efficiency}

At the early flowering stage, ${ }^{15} \mathrm{~N}$ recovery efficiency $\left({ }^{15} \mathrm{NRE}\right)$ of root, stem and leaves under low nitrogen treatment increased by 2.22 and $0.77,9.66$ and 6.95 , 21.22 and 14.66 percentage points compared to those under high nitrogen treatment in HZ9 and HS5, 
N use Efficiency of Winter Rapeseed and Sesame / Int. J. Agric. Biol., Vol. 19, No. 4, 2017

Table 4: ${ }^{15} \mathrm{~N}$ recovery efficiency and variance analysis of different organs in different stages $\left({ }^{15} \mathrm{NRE} / \%\right)$

\begin{tabular}{|c|c|c|c|c|c|c|c|c|c|}
\hline \multirow[t]{2}{*}{ Treatment } & \multicolumn{4}{|c|}{ Early Flowering Stage } & \multicolumn{5}{|c|}{ Maturity Stage } \\
\hline & Root & Stem & Leaf & Total & Grain & Pericarp & Stem & Root & Total \\
\hline \multicolumn{10}{|l|}{ HZ9 } \\
\hline $\mathrm{N}_{1}$ & 4.14 & 19.44 & 45.17 & 68.75 & 41.65 & 10.30 & 5.98 & 0.82 & 58.75 \\
\hline $\mathrm{N}_{2}$ & 1.92 & 9.78 & 23.95 & 35.65 & 37.61 & 11.13 & 6.50 & 1.03 & 56.27 \\
\hline $\mathrm{T}_{1}$ & 3.02 & 11.84 & 36.67 & 51.53 & 38.80 & 8.25 & 5.47 & 0.90 & 53.42 \\
\hline $\mathrm{T}_{2}$ & 3.04 & 17.38 & 32.45 & 52.87 & 40.47 & 13.18 & 7.00 & 0.95 & 61.60 \\
\hline $\mathrm{N}$ & ** & ** & ** & ** & ns & ns & ns & $*$ & ns \\
\hline $\mathrm{T}$ & ns & $* *$ & $*$ & ns & ns & $*$ & ns & $\mathrm{ns}$ & $* *$ \\
\hline $\mathrm{N} \times \mathrm{T}$ & $\mathrm{ns}$ & $* *$ & ns & * & $\mathrm{ns}$ & ns & ns & ns & ns \\
\hline \multicolumn{10}{|l|}{ HS5 } \\
\hline $\mathrm{N}_{1}$ & 3.42 & 18.54 & 42.29 & 64.26 & 42.09 & 9.00 & 3.65 & 0.77 & 55.51 \\
\hline $\mathrm{N}_{2}$ & 2.65 & 11.59 & 27.63 & 41.87 & 30.50 & 10.83 & 6.96 & 1.33 & 49.62 \\
\hline $\mathrm{T}_{1}$ & 3.25 & 13.35 & 36.86 & 53.45 & 33.19 & 8.57 & 5.31 & 1.20 & 48.27 \\
\hline $\mathrm{T}_{2}$ & 2.82 & 16.79 & 33.07 & 52.68 & 39.40 & 11.26 & 5.30 & 0.90 & 56.85 \\
\hline $\mathrm{N}$ & * & $* *$ & ** & ** & ** & $* *$ & $* *$ & $* *$ & $* *$ \\
\hline $\mathrm{T}$ & $\mathrm{ns}$ & $*$ & $\mathrm{~ns}$ & $\mathrm{~ns}$ & $* *$ & $* *$ & $\mathrm{~ns}$ & $* *$ & $* *$ \\
\hline $\mathrm{N} \times \mathrm{T}$ & ns & ns & $\mathrm{ns}$ & ns & $\mathrm{ns}$ & ** & ns & $\mathrm{ns}$ & ns \\
\hline
\end{tabular}

$\mathrm{N}, \mathrm{T}$ and $\mathrm{N} \times \mathrm{T}$ represented nitrogen application rate and nitrogen application time, interaction of nitrogen application rate and nitrogen application time respectively; *, ** and ns indicated significant treatment effects at $\mathrm{P} \leqslant 0.05, \mathrm{P} \leqslant 0.01$ and not significant, respectively; HZ9 and HS5 represented Huayouza No.9 and Huashuang No.5, respectively; $\mathrm{N}_{1}$ and $\mathrm{N}_{2}$ represented 0.15 and $0.30 \mathrm{~g} \mathrm{~N} . \mathrm{kg}^{-1}$ soil; $\mathrm{T}_{1}$ and $\mathrm{T}_{2}$ represented basal labelling and topdressing labelling

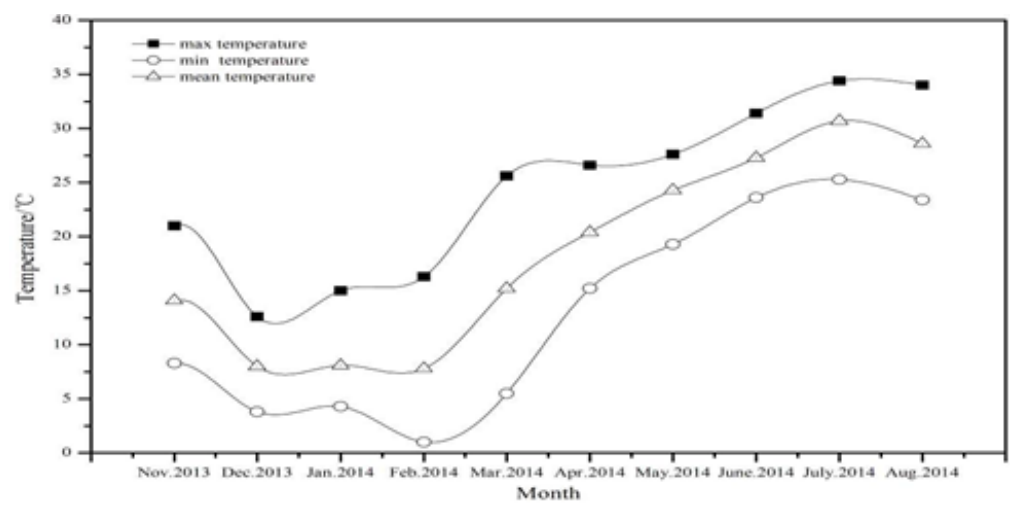

Fig. 1: The variation of monthly maximum (max), minimum (min) and mean temperature (mean) in glasshouse

respectively. ${ }^{15} \mathrm{~N}$ recovery efficiency $\left({ }^{15} \mathrm{NRE}\right)$ of $\mathrm{HS} 5$ under low nitrogen was significantly increased by 5.89 percentage points compared to that of high nitrogen $(49.62 \%)$ during the maturity stage, with the most obvious difference observed in grain (+11.59 percentage points). However, the ${ }^{15} \mathrm{NRE}$ values of the other organs under low nitrogen treatment were decreased by $0.56 \sim 3.31$ percentage points compared to those under high nitrogen treatment (Table 4), but no significant difference was observed in HZ9 (56.27 58.75\%) between the two N levels.

${ }^{15} \mathrm{NRE}$ under topdressing $(61.60 \%$ and $56.85 \%)$ increased by 8.18 and 8.58 percentage points as compared to that under basal in HZ9 and HS5, respectively, and the main difference was observed in grain and pericarp during the maturity stage. Under the basal conditions, plant leaves showed the highest ${ }^{15} \mathrm{NRE}$ among all plant organs at the early flowering stage. At the mature stage, ${ }^{15} \mathrm{NRE}$ of plant root and stem decreased by $2.05 \sim 2.12$ and $6.37 \sim 8.04$ percentage points compared to that at the early flowering stage. Under the topdressing condition, the ${ }^{15} \mathrm{NRE}$ values of plant root, stem and leaf at the early flowering stage were $2.82 \sim 3.04 \%, 16.79 \sim 17.38 \%$ and $32.45 \sim 33.07 \%$ in HZ9 and HS5, respectively. At the maturity stage, the ${ }^{15} \mathrm{NRE}$ of plant root and stem was $0.90 \sim 7.00 \%$, whereas that of grain and pericarp was $39.40 \sim 40.47 \%$ and $11.26 \sim 13.18 \%$, respectively (Table 4). There were significant interactions of nitrogen application rate and time with the $15 \mathrm{NRE}$ of plant stem and the total in HZ9 at the early flowering stage, but only that of the pericarp was noted at the maturity stage.

\section{N Transport Efficiency}

Under low nitrogen treatment, the ${ }^{15} \mathrm{~N}$ transport efficiency $\left({ }^{15} \mathrm{NTE}\right)$ of plant stem was significantly higher than that under high nitrogen treatment in HZ9 and HS5, but the opposite trend was noticed in plant leaves; ${ }^{15} \mathrm{NTE}$ in plant root was higher than that under high nitrogen treatment, but a significant difference was only found in HZ9. Total ${ }^{15}$ NTE significantly increased by 4.76 and 3.15 percentage points, and it was notably higher under low 
Table 5: Effect of treatments of previous rapeseed on yield, total nitrogen, ${ }^{15} \mathrm{~N}_{\mathrm{dff}}$ of different organs and ${ }^{15} \mathrm{NRE}$ of sesame at mature stage

\begin{tabular}{|c|c|c|c|c|c|c|c|}
\hline \multirow[t]{2}{*}{ Treatment } & \multirow[t]{2}{*}{ Yield/g/plant } & \multirow[t]{2}{*}{ Total N/g/plant } & \multicolumn{4}{|c|}{$\mathrm{N}_{\mathrm{dff}} / \%$} & \multirow[t]{2}{*}{${ }^{15} \mathrm{NRE}$} \\
\hline & & & Stem & Pericarp & Grain & Total & \\
\hline \multicolumn{8}{|l|}{ HZ9 } \\
\hline $\mathrm{N}_{1}$ & 0.32 & 0.02 & 10.97 & 12.84 & 14.39 & 13.33 & 1.43 \\
\hline $\mathrm{N}_{2}$ & 0.70 & 0.04 & 16.94 & 18.33 & 19.60 & 19.05 & 1.81 \\
\hline $\mathrm{T}_{1}$ & 0.58 & 0.03 & 18.10 & 20.00 & 22.59 & 21.39 & 2.02 \\
\hline $\mathrm{T}_{2}$ & 0.43 & 0.02 & 9.81 & 11.17 & 11.40 & 10.99 & 1.22 \\
\hline $\mathrm{N}$ & $* *$ & $* *$ & $* *$ & $* *$ & $* *$ & $* *$ & $*$ \\
\hline $\mathrm{T}$ & $* *$ & $* *$ & $* *$ & $* *$ & $* *$ & $* *$ & $* *$ \\
\hline $\mathrm{N} \times \mathrm{T}$ & ns & ns & ns & $*$ & ns & ns & ns \\
\hline \multicolumn{8}{|l|}{ HS5 } \\
\hline $\mathrm{N}_{1}$ & 0.51 & 0.03 & 11.48 & 12.74 & 13.76 & 13.33 & 1.83 \\
\hline $\mathrm{N}_{2}$ & 0.59 & 0.03 & 16.29 & 18.05 & 19.91 & 19.20 & 1.44 \\
\hline $\mathrm{T}_{1}$ & 0.50 & 0.03 & 18.47 & 20.91 & 22.81 & 21.98 & 1.80 \\
\hline$T_{2}$ & 0.59 & 0.03 & 9.30 & 9.88 & 10.86 & 10.54 & 1.46 \\
\hline $\mathrm{N}$ & ns & ns & $* *$ & $* *$ & $* *$ & $* *$ & $* *$ \\
\hline $\mathrm{T}$ & ns & ns & $* *$ & $* *$ & ** & $* *$ & $*$ \\
\hline $\mathrm{N} \times \mathrm{T}$ & $\mathrm{ns}$ & $\mathrm{ns}$ & $\mathrm{ns}$ & $* *$ & $\mathrm{~ns}$ & $\mathrm{~ns}$ & * \\
\hline
\end{tabular}

$\mathrm{N}, \mathrm{T}$ and $\mathrm{N} \times \mathrm{T}$, represented nitrogen application rate and nitrogen application time, interaction of nitrogen application rate and nitrogen application time, respectively; *, ** and ns indicated significant treatment effects at $\mathrm{P} \leqslant 0.05, \mathrm{P} \leqslant 0.01$ and not significant, respectively;HZ9 and HS5 represented Huayouza No.9 and Huashuang No.5, respectively; $\mathrm{N}_{1}$ and $\mathrm{N}_{2}$ represented 0.15 and $0.30 \mathrm{~g} \mathrm{N.kg-1}$ soil; $\mathrm{T}_{1}$ and $\mathrm{T}_{2}$ represented basal labelling and topdressing labelling
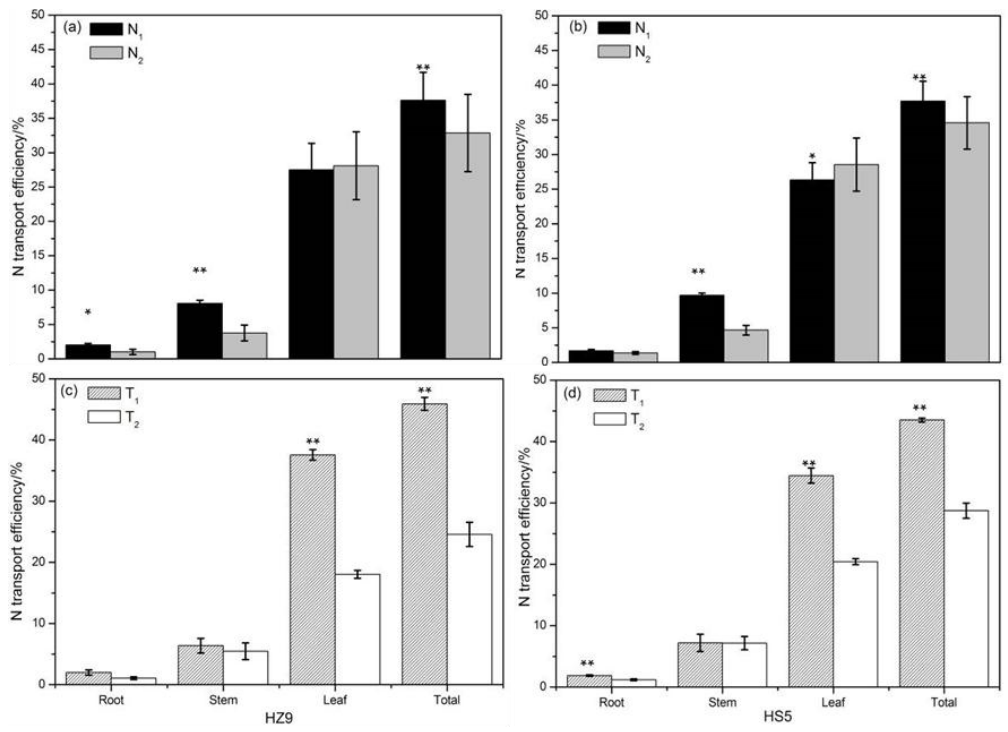

Fig. 2: ${ }^{15} \mathrm{~N}$ transport efficiency from vegetative organs to pod after the early flowering stage of rapeseed

$\mathrm{N}$ and T represented nitrogen application rate and nitrogen application time, respectively; ${ }^{*}, * *$ and ns indicated significant treatment effects at $\mathrm{P} \leqslant 0.05, \mathrm{P} \leqslant$ 0.01 and not significant, respectively; HZ9 and HS5 represented Huayouza No.9 and Huashuang No.5, respectively; $\mathrm{N}_{1}$ and $\mathrm{N}_{2}$ represented 0.15 and $0.30 \mathrm{~g}$ N.kg ${ }^{-1}$ soil; $T_{1}$ and $T_{2}$ represented basal labelling and topdressing labeling

nitrogen treatment than under high nitrogen treatment in HZ9 and HS5 (Fig. 2a and 2b).

The total ${ }^{15} \mathrm{NTE}$ of basal application was significantly increased by 21.33 and 14.77 percentage points compared to that of topdressing in HZ9 and HS5, respectively. For plant leaves, ${ }^{15} \mathrm{NTE}$ of basal nitrogen significantly increased by $19.52 \%$ and $14.02 \%$ compared to that of topdressing, respectively; meanwhile, a similar tendency was observed for total ${ }^{15}$ NTE. However, for root, a significant difference of ${ }^{15}$ NTE was only observed in HS5 (Fig. 2c and d). Hence, the total $\mathrm{N}$ transport efficiency of low nitrogen and basal were significantly higher than that of high nitrogen and topdressing, with the maximum difference of $\mathrm{N}$ application rate among all plant organs observed in stem (4.33 5.03\%), and that of application time observed in leaves (9.52 14.02\%).

\section{Residual Effects of N Fertilizer by Subsequent Sesame}

The sesame yield and total nitrogen content of plant underground under high nitrogen treatment were significantly increased by $118.75 \%$ and $100 \%$ in HZ9 compared to low nitrogen treatment, respectively. The sesame yield of nitrogen fertilizer treatment in rapeseed 
reason was increased by $26.00 \sim 89.19 \%$ than that of the control $\left(\mathrm{N}_{0}, 0.37 \mathrm{~g} /\right.$ plant). Meanwhile, the $\mathrm{N}_{\text {dff }}$ values of all organs under high nitrogen treatment were 4.80 6.14 percentage points higher than those under low nitrogen treatment in HZ9 and HS5. However, there was a significant difference in the ${ }^{15} \mathrm{NRE}$ of sesame between the two $\mathrm{N}$ levels; with the ${ }^{15} \mathrm{NRE}$ of $\mathrm{N}_{2}$ being higher than that of $\mathrm{N}_{1}$ in HZ9, but it was the opposite in HS5, with a value of $1.44 \sim 1.83 \%$ (Table 5).

No significant differences were observed in the sesame yield and total nitrogen content of the plant above the ground in HZ9 between basal and topdressing. The sesame yield of basal and topdressing in rapeseed reason was increased by $16.22 \sim 59.50 \%$ relative to that of the control $\left(\mathrm{N}_{0}, 0.37 \mathrm{~g} / \mathrm{plant}\right)$. The $\mathrm{N}_{\text {dff }}$ value of each organ of sesame under the basal condition increased by $8.29 \sim 11.96$ percentage points compared to that under the topdressing condition. The ${ }^{15} \mathrm{NRE}$ value of basal $(1.83 \sim 2.02 \%)$ was significantly increased by $0.34 \sim 0.80$ percentage points compared to topdressing (1.22 1.46\%) in HZ9 and HS5 (Table 5). Meanwhile, significant interactions were observed for $\mathrm{N} \times \mathrm{T}$ on $\mathrm{N}_{\text {dff }}$ of pericarp in HZ9 and HS5 and ${ }^{15} \mathrm{NRE}$ of whole plant in HS5 (Table 5).

\section{Discussion}

In the present study, the total nitrogen recovery efficiency of the two rapeseed varieties decreased with the increase of nitrogen level at the maturity stage, which was similar to several previous studies (Adriana et al., 2002; Franzaring et al., 2012). Meanwhile, the total ${ }^{15} \mathrm{~N}$ recovery efficiency of topdressing was significantly higher than that of basal at the maturity stage, with the difference between them being 8.18 and 8.58 percentage points in HZ9 and HS5, respectively (Table 4). However, Cai et al. (1995) reported that the topdressing recovery efficiency $(33.40 \%)$ was significantly lower than that of basal $(44.00 \%)$ at the flowering stage, which may be due to the different sampling time. In this study, the sampling was performed at the maturity stage, while it was performed 35 days after topdressing in the research of Cai et al. (1995). The $\mathrm{N}$ recovery efficiency of topdressing was higher than that of basal under rapeseed normal growth conditions, probably because the stemelongation stage is the key time for vegetative growth and reproductive growth of rapeseed, when the accumulation of nutrient could not meet the requirements of the rapid growth of rapeseed and most of the basal nitrogen fertilizer has been absorbed at the seedling stage, thus little nitrogen fertilizer can be absorbed by rapeseed. When supplied by topdressing, $\mathrm{N}$ fertilizer could be much better absorbed at the stem elongation stage. Therefore, reducing basal nitrogen and increasing topdressing nitrogen could promote the absorption of more fertilizer nitrogen by rapeseed plant, and also improved the nitrogen recovery efficiency and protect the environment from contamination. The ${ }^{15} \mathrm{~N}$ recovery efficiency of grain was 33.19 40.47\% under basal and topdressing labelling conditions (Table 4), which was lower than the $41.00 \sim 50.70 \%$ of the spring rapeseed reported by Franzaring et al. (2012), but it was higher than the value of $25.00 \%$ for the winter oilseed rape reported by Macdonald et al. (1997). The differences in the ${ }^{15} \mathrm{~N}$ recovery efficiency of grain might be related to different soil conditions, climate characteristics or varieties (Macdonald et al., 1997).

In this study, ${ }^{15} \mathrm{~N}$ transport efficiency was obviously affected by nitrogen application rate and time. Specifically, the low nitrogen treatment showed significantly higher ${ }^{15} \mathrm{~N}$ transport efficiency than high nitrogen treatment with a difference range of $3.15 \sim 4.76 \%$ and the total ${ }^{15} \mathrm{~N}$ transport efficiency of the two varieties was $32.86 \sim 34.55 \%$ (Fig. 2a and $b$ ). The total ${ }^{15} \mathrm{~N}$ transport efficiency of basal treatment was significantly higher than that of topdressing, with a difference range of $14.77 \sim 21.33 \%$, and the total ${ }^{15} \mathrm{~N}$ transport efficiency of the two varieties was $24.58 \sim 45.91 \%$ (Fig. 2c and d). These results demonstrated that the effect of nitrogen application time on $\mathrm{N}$ transport efficiency was greater than that of nitrogen application rate, and the transport of nitrogen from leaf was dominant regardless of application rate and time. However, previous researchers reported that the apparent nitrogen transport efficiency of the rapeseed grain was about $48.00 \sim 65.00 \%$ from vegetative tissues, which was higher than that in this study (Hocking et al., 1997; Rossato et al., 2001; Malagoli et al., 2005; Gombert et al., 2010). This difference may be attributed to the separate calculation of the ${ }^{15} \mathrm{~N}$ transport efficiency of basal and topdressing, and there was no distinction between grain and pericarp. The application rate mainly affected the ${ }^{15} \mathrm{~N}$ transport efficiency of stem, while the application time mainly affected that of leaf, and their change trend was similar to that of total ${ }^{15} \mathrm{~N}$ transport efficiency. Thus, the transport efficiency of rapeseed stem can be used as a good indicator for the whole plant at different $\mathrm{N}$ levels, while that of rapeseed leaf can be used as a good indicator for the whole plant at different application time. However, the specific influence mechanism needs to be further studied. A proper reduction of basal nitrogen application rate and an increase of topdressing nitrogen could promote the absorption of more fertilizer nitrogen in rapeseed plant, and also improve nitrogen recovery efficiency and protect environment. In view of high $\mathrm{N}$ transport efficiency, a certain application rate of basal $\mathrm{N}$ should be maintained to improve the plant nitrogen transport efficiency. To maximize the rapeseed recovery efficiency and transport efficiency, it is necessary to establish proper total nitrogen and a desirable proportion between basal and topdressing to coordinate the crop source-sink for the high yield and high efficiency of rapeseed.

In this study, significant differences were found in the sesame yield and total nitrogen content between nitrogen application rates. Meanwhile, significant differences were also observed in the $\mathrm{N}$ recovery efficiency of soil residual nitrogen in sesame between nitrogen application time 
points. The ${ }^{15} \mathrm{~N}$ recovery efficiency $\left({ }^{15} \mathrm{NRE}\right)$ values of basal and topdressing were $1.80 \sim 2.02 \%$ and $1.22 \sim 1.46 \%$, respectively. The ${ }^{15} \mathrm{NRE}$ of $\mathrm{N}_{1}$ and $\mathrm{N}_{2}$ was $1.43 \%$ and $1.81 \%$ in HZ9, but $1.83 \%$ and $1.44 \%$ in HS5 (Table 5). The average ${ }^{15} \mathrm{NRE}$ of sesame (1.34 1.91\%) was lower than that of the winter wheat without fertilization (6.3\%) reported by (Macdonald et al. 2002). It suggested that the ${ }^{15} \mathrm{NRE}$ of sesame was affected by the previous rapeseed, even without fertilizer added during sesame growth, which was similar with the report by Xu et al. (2015) and Macdonald et al. (2002), but the value was low, and it could be attributed to the immobilization of large amounts of fertilizer $\mathrm{N}$ in organic matter (Ichir et al., 2003). It could be meaningful to study whether $\mathrm{N}$ recovery efficiency of rapeseed residual soil nitrogen can be improved by adding a certain amount of nitrogen, phosphorus or potassium fertilizer or NPK complex fertilizer as basal or topdressing during sesame growth. Hence, the application of a suitable amount of fertilizer to rapeseed followed by the growth of sesame with less fertilizer requirement after rapeseed harvest not only can reduce the consumption of nitrogen fertilizer, but also can make full use of soil residual nitrogen and increase the economic income of farmers.

\section{Conclusion}

Appropriate application rate and time of $\mathrm{N}$ fertilizer is essential for improving crop productivity, economic management, $\mathrm{N}$ use efficiency and sustainability of the environment. $\mathrm{N}$ recovery efficiency of topdressing was significantly increased by about 8.0 percentage points compared with basal application, and the change range of $\mathrm{N}$ recovery efficiency of $\mathrm{N}$ application time was greater as compared to $\mathrm{N}$ application rate. Total ${ }^{15} \mathrm{~N}$ transport efficiency was significantly higher when $\mathrm{N}$ was applied in the lower rate as a basal dose compared to application of $\mathrm{N}$ at higher rate as a topdressing, and significantly higher difference of $\mathrm{N}$ application rate among plant organs was observed in stem $(4.33 \% \sim 5.03 \%)$, whereas in case of $\mathrm{N}$ application time was observed in leaves (9.52\% 14.02\%). Meanwhile, the $1.34 \% \sim 1.91 \%$ of rapeseed residual soil nitrogen was recovered by the succeeding sesame. Overall, higher $\mathrm{N}$ recovery and transport efficiency can be achieved by reducing nitrogen application rate and increasing the proportion of topdressing. Further studies need to focus on the improvement of the recovery efficiency of soil residual $\mathrm{N}$ through fertilizer application to sesame.

\section{Acknowledgments}

The research was funded by the National Key Technology Research and Development Program (2010BAD-01B01) and China Agricultural Research System (CARS-13 (Rapeseed) and CARS-15 (Sesame). The authors sincerely thank Associate Prof. Hanchang Zhu from College of Foreign Languages, Huazhong Agricultural University for revising the paper.

\section{References}

Adriana, M., L.N. Tamagno, R. Bezus and S.J. Sarandón, 2002. Nitrogen accumulation, partition, and nitrogen use efficiency in canola under different nitrogen availabilities. Commun. Soil Sci. Plant Anal., 33: 3-4

Cai, G.X., G.H. Peng, Y.W. Wu, M.T. Ma, S.W. Gan and C.F. Men, 1995. Fate of urea nitrogen applied to rape grown on a red soil and efficiency of urea in raising rape yield. Pedosphere, 5: 107114

Choudhury, T.M.A. and Y.M. Khanif, 2001. Evaluation of effects of nitrogen and magnesium fertilization on rice yield and fertilizer nitrogen efficiency using ${ }^{15} \mathrm{~N}$ tracer technique. J. Plant Nutr., 24: $855-871$

Dresbøll, D.B., I.S. Rasmussen and K. Thorup-Kristensen, 2016. The significance of litter loss and root growth on nitrogen efficiency in normal and semi-dwarf winter oilseed rape genotypes. Field Crops Res., 186: 166-178

Franzaring, J., G. Gensheimer, S. Weller, I. Schmid and A. Fangmeier, 2012. Allocation and remobilisation of nitrogen in spring oilseed rape (Brassica napus L. cv. Mozart) as affected by N supply and elevated $\mathrm{CO}_{2}$. Environ. Exp. Bot., 83: 12-22

Gan, Y., S.S. Malhi, S. Brandt, F. Katepa-Mupondwa and C. Stevenson, 2008. Nitrogen use efficiency and nitrogen uptake of juncea canola under diverse environments. Agron. J., 100: 285-295

Gironde, A., P. Etienne, J. Trouverie, A. Bouchereau, F.L. Caherec, L. Leport, M. Orsel, M.F. Niogret, N. Nesi, D. Carole, F. Soulay, C. Masclaux-Daubresse and J.C. Avice, 2015a. The contrasting N management of two oilseed rape genotypes reveals the mechanisms of proteolysis associated with leaf $\mathrm{N}$ remobilization and the respective contributions of leaves and stems to $\mathrm{N}$ storage and remobilization during seed filling. BMC Plant Biol., 15: 59

Gironde, A., M. Poret, P. Etienne, J. Trouverie, A. Bouchereau, F.L. Caherec, L. Leport, M. Orsel, M.F. Niogret, C. Deleu and J.C. Avice, $2015 \mathrm{~b}$. A profiling approach of the natural variability of foliar N remobilization at the rosette stage gives clues to understand the limiting processes involved in the low $\mathrm{N}$ use efficiency of winter oilseed rape. J. Exp. Bot., 66: 2461-2473

Gombert, J., F.L. Dily, J. Lothier, P. Etienne, L. Rossato, J.-M. Allirand, A. Jullien, A. Savin and A. Ourry, 2010. Effect of nitrogen fertilization on nitrogen dynamics in oilseed rape using ${ }^{15} \mathrm{~N}$-labeling field experiment. J. Plant Nutr. Soil Sci., 173: 875-884

Hocking, P.J., P.J. Randall and D. DeMarco, 1997. The response of dryland canola to nitrogen fertilizer: partitioning and mobilization of dry matter and nitrogen, and nitrogen effects on yield components. Field Crops Res., 54: 201-220

Ichir, L.L., M. Ismaili and G. Hofman, 2003. Recovery of ${ }^{15} \mathrm{~N}$ labeled wheat residue and residual effects of $\mathrm{N}$ fertilization in a wheat-wheat cropping system under Mediterranean conditions. Nutr. Cycl. Agroecosys., 66: 201-207

Ji, C.R., S.Q. Li, W.M. Wu, Y.M. Wei, X.C. Zhang and M.A. Shao, 2005. Effect of $\mathrm{N}$ fertilization on $\mathrm{N}$ trans location of different winter wheat cultivars during grain filling period in sub-humid farmland ecologic system. Plant Nutr. Fert. Sci., 11: 569-577

Johnson, E.N., S.S. Malhi, L.M. Hall and S. Phelps, 2013. Effects of nitrogen fertilizer application on seed yield, $\mathrm{N}$ uptake, $\mathrm{N}$ use efficiency, and seed quality of Brassica carinata. Can. J. Plant Sci., 93: 1073-1081

Koeslin-Findeklee, F. and W.J. Horst, 2016. Contribution of nitrogen uptake and retranslocation during reproductive growth to the nitrogen efficiency of winter oilseed-rape cultivars (Brassica napus L.) Differing in Leaf Senescence. Agronomy, 6: 1

Li, H., R.H. Cong, T. Ren, X.K. Li, C.B. Ma, L. Zheng, Z. Zhang and J.W. $\mathrm{Lu}, 2015$. Yield response to $\mathrm{N}$ fertilizer and optimum $\mathrm{N}$ rate of winter oilseed rape under different soil indigenous $\mathrm{N}$ supplies. Field Crops Res., 181: 52-59

Macdonald, A.J., P.R. Poulton, D.S. Powlson and D.S. Jenkinson, 1997. Effects of season, soil type and cropping on recoveries, residues and losses of ${ }^{15} \mathrm{~N}$-labelled fertilizer applied to arable crops in spring. $J$. Agric. Sci., 129: 125-154 
Macdonald, A.J., P.R. Poulton, E.A. Stockdale, D.S. Powlson and D.S. Jenkinson, 2002. The fate of residual ${ }^{15} \mathrm{~N}$-labelled fertilizer in arable soils: its availability to subsequent crops and retention in soil. Plant Soil, 246: 123-137

Malagoli, P., P. Laine, L. Rossato and A. Ourry, 2005. Dynamics of nitrogen uptake and mobilization in field-grown winter oilseed rape (Brassica napus) from stem extension to harvest: I. Global $\mathrm{N}$ flows between vegetative and reproductive tissues in relation to leaf fall and their residual N. Ann. Bot., 95: 853-861

Rossato, L., P. Laine and A. Ourry, 2001. Nitrogen storage and remobilization in Brassica napus L. during the growth cycle: nitrogen fluxes within the plant and changes in soluble protein patterns. J. Exp. Bot., 52: 1655-1663

Schulte-auf"m-Erley, G., T. Behrens, A. Ulas, F. Wiesler and W.J. Horst, 2011. Agronomic traits contributing to nitrogen efficiency of winter oilseed rape cultivars. Field Crops Res., 124: 114-123

Sepaskhah, A.R. and A. Tafteh, 2012. Yield and nitrogen leaching in rapeseed field under different nitrogen rates and water saving irrigation. Agric. Water Manage., 112: 55-62
Wang, C., J. Hai, J. Yang, J. Tian, W. Chen, T. Chen, H. Luo, H. Wang, 2016. Influence of leaf and silique photosynthesis on seeds yield and seeds oil quality of oilseed rape (Brassica napus L.). Eur. J. Agron., 74: $112-118$

Wang, X., A. Mathieu, P.H. Cournède, J.M. Allirand, A. Jullien, P. de Reffye and B.G. Zhang, 2011. Variability and regulation of the number of ovules, seeds and pods according to assimilate availability in winter oilseed rape (Brassica napus L.). Field Crops Res., 122: 60-69

Xu, H.G., G.R. Zhong, J.J. Lin, Y.F. Ding, G.H. Li, S.H. Wang, Z.H. Liu, S. Tang and C.Q. Ding, 2015. Effect of nitrogen management during the panicle stage in rice on the nitrogen utilization of rice and succeeding wheat crops. Eur. J. Agron., 70: 41-47

Zou, J., J.W. Lu, F. Chen, Y.S. Li and X.K. Li, 2011. Study on yield increasing and nutrientuptake effect bynitrogen application and nitrogen use efficiency for winter rapeseed. Sci. Agric. Sin.,44: 745-752

(Received 11 January 2017; Accepted 13 march 2017) 